\title{
The Mediating Role of Work Satisfaction in the Effect of Professional Identity and Organizational Support on the Intention to Quit from Work
}

\author{
Mei Ie ${ }^{1 *}$, Daniel Denaldo ${ }^{1}$, Hetty Karunia Tunjungsari ${ }^{1}$ \\ ${ }^{1}$ Faculty of Economics and Business, Universitas Tarumanagara, Jakarta 11470, Indonesia \\ ${ }^{*}$ Corresponding author. Email: meii@fe.untar.ac.id
}

\begin{abstract}
Insurance industry is one of the essential sectors that are considered vital in this globalization era. Although this industry in Indonesia is experiencing growth, there is a problem that has not been solved, which is specifically about the low retention-rate of insurance agents. Therefore, the purpose of this study was to examine the effect of professional identity and perceived organizational support on the intention to quit from work with job satisfaction as a mediating role among the XYZ insurance agents. The sample was taken by using the purposive sampling method consisting of 200 respondents, and the data analysis used AMOS software version 21. The results of this study indicate that both professional identity and perceived organizational support have a positive and direct effect on job satisfaction, while job satisfaction has a negative and direct effect on the intention to quit. Professional identity and perceived organizational support have a negative and indirect effect on the intention to quit through job satisfaction as the fully mediating variable.
\end{abstract}

Keywords: professional identity, perceived organizational support, job satisfaction, intention to quit

\section{INTRODUCTION}

Insurance industry is one of the essential sectors that are considered vital in this era of globalization, which is useful for protecting an individual from the risks originating from natural factors and human beings' actions, by transferring these risks to the insurance companies [1]. Over time, in today's modern society, insurance has become one of the basic necessities, especially the life and health insurance. In Indonesia, this is evidenced by the increasing demand for insurance which goes hand-in-hand with an increase in income and public awareness of the importance of anticipating the risks [2]. Although the insurance industry is experiencing growth, there is a problem that cannot be resolved, namely the low retention-rate of insurance agents [3].

Quitting behavior is a situation that describes the condition of a worker leaving the organization where he / she works. If a worker is dismissed unilaterally by the organization, it is called involuntary turnover, while a worker who decides to leave the organization on his / her own decision is known as voluntary turnover [4]. Previous research stated that quitting behavior can be realized into a concrete action as a result of a strong urge known as the intention to quit [5]. The intention to quit is a form of intention that is consciously and deliberately decided by a worker which shows a probability for him or her to leave the organization voluntarily in the future in which there is an attraction to find a new job [6].
Many studies analyze the factors related to the intention to quit and show a significant correlation of various external and internal factors that can coordinate with each other and cause a combined effect, resulting in the intention to quit [5]. The factor that is considered to have the most significant influence on wanting to quit is the job satisfaction, which has been proven through various studies, one of which was conducted on 320 academic and nonacademic staffs in Nigeria [6]. Meanwhile, according to other research conducted in Virginia, another factor that also affects the intention to quit is the organizational support [7]. Research on 457 nurses at the Regional General Hospital in Cairo proved that professional identity also plays an important role in the intention to quit [8]. Moreover, [5] also found that job satisfaction is a mediating variable in the relationship between organizational support and the intention to quit.

In Indonesia, recently the growth of insurance sector has increased rapidly [2]. Based on the 2013 Insurance Sector Statistical Data issued by the Financial Services Authority $(\mathrm{OJK})$, it shows that the total life-insurance companies having a business license to operate in Indonesia were 51 companies [9]. One among the insurance company is XYZ, which is one of the largest and best insurance companies in Indonesia [10]. This is evidenced by the Top Life Insurance and The Best Sharia awards in 2018. 


\section{BACKGROUND}

\subsection{Professional Identity}

Professional identity is a unique professional perception that a worker has about him / herself in relation to the work he / she does according to specific abilities which is an important aspect in realizing the work-related success and organizational goals.

Based on the research conducted by [11] and [5], professional identity can be measured by using two dimensions, namely:

1) Community membership

Through community membership, a worker can define who he / she is through participation and proving him / herself to other people around, both known and unknown.

2) Learning lane

Through the learning path, a worker can define him /herself based on the position and job role he / she is doing now and in the future.

\subsection{Organizational Support}

Organizational support is a global perception that a worker has about the organization where he or she works in an effort to maintain welfare, respect for work contributions, and increase the ability and quality of workers themselves, in order to increase work effectiveness and productivity in the organization.

The literature written by [12] and the research conducted by [13] stated that basically there are three main dimensions of organizational support, namely:

1) Justice

A fair attitude that is applied repeatedly by organizations is considered to be one of the dimensions of organizational support. This fair attitude is shown in the structural and social aspects that apply in day-to-day operations, or more simply, justice is shown through organizational policies and fairness in treatment.

2) Support from superiors

In an organization, superiors are individuals who have the responsibility to orient, direct, assess, and evaluate performance, as well as paying attention to the socioeconomic welfare of the workers. So, a good boss is believed to be an indication of organizational support.

3) Job condition

Research has shown that in human-resource practices, the recognition received by a worker from an organization is believed to be one dimension of the organizational support. This recognition can be shown through appreciation and a comfortable working environment such as: salary increases and promotions, job security, autonomy rights, pressure at work, training, and organizational size.

\subsection{Work Decision}

The definition of job satisfaction is a positive attitude from the workers which includes feelings and behavior towards their work which is shown in the form of appreciation by achieving one of the important values of the job.

[14] and [15] stated that there are five main dimensions of job satisfaction which include:

1) The work itself

Jobs that can be said to provide satisfaction are interesting and challenging jobs, jobs that vary, and jobs that can develop abilities.

2) Organization management

Organizations that have a good management system such as a clear work bureaucracy, a system for promotion and clear career paths, and good leadership attitudes, are considered to support job satisfaction.

3) Work environment

A pleasant work environment and good co-workers can increase job satisfaction.

\subsection{Intention to Quit}

The intention to quit is the intention of a worker to withdraw from the organization it serves and is followed by a series of concrete behaviors on the basis of his / her own choice so that the job position must be replaced by someone else.

Based on the research conducted by [5], the dimensions of the intention to quit consist of:

1) The idea of quitting

This is the existence of a worker thinking to leave an organization.

2) Intention to quit

There is an attitude of a worker that shows the indications of leaving such as minimizing work effort and canceling important jobs.

3) Intention to seek

There is an attitude of a worker to look for other organizational alternatives, and ask the questions related to other organizations.

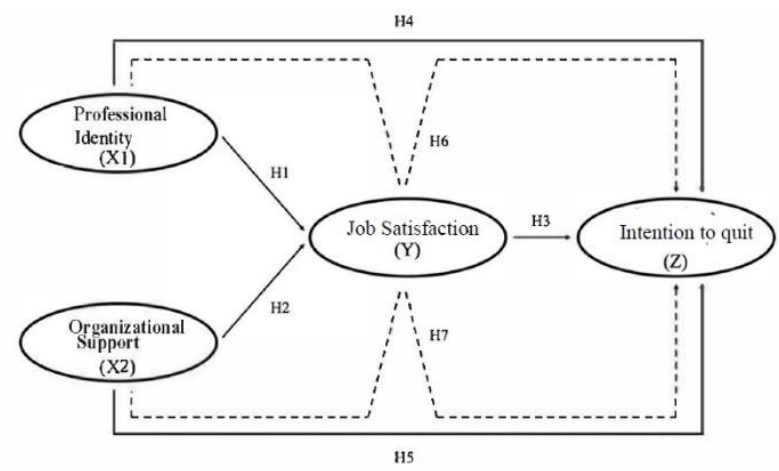

Figure 1 Theoritical framework

Based on the theoretical framework above, the hypotheses in this study can be described as follows: 
$\mathrm{H}_{1}$ : Professional identity has an effect on job satisfaction among the XYZ insurance agents.

$\mathrm{H}_{2}$ : Organizational support has an effect on job satisfaction among the $\mathrm{XYZ}$ insurance agents.

$\mathrm{H}_{3}$ : Job satisfaction has an effect on the intention to quit among the insurance agents of XYZ.

$\mathrm{H}_{4}$ : Professional identity has an effect on the intention to quit among the insurance agents of XYZ.

$\mathrm{H}_{5}$ : Organizational support has an effect on the intention to quit among the insurance agents of XYZ.

$\mathrm{H}_{6}$ : Professional identity has an effect on the intention to quit with job satisfaction as a mediator among the $\mathrm{XYZ}$ insurance agents.

$\mathrm{H}_{7}$ : Organizational support has an effect on the intention to quit with job satisfaction as a mediator among the $\mathrm{XYZ}$ insurance agents.

\section{METHODOLOGY}

This research used the method of causal analysis. The dependent variable in this study is the intention to quit, while the independent variables are professional identity and organizational support, with job satisfaction as a mediating variable between the independent and dependent variables.

The population contained in this study were all insurance agents of XYZ Company, totaling 3,000 people. In this study, the sample taken was all XYZ agents in the NMY Unit, totaling 200 people. The basis for selecting the number of samples included in this study is based on the theory presented by [16], namely that the number of more than 30 and less than 500 is commonly used in many studies. The determination of the sample in this study was carried out by using a non-probability sampling type, namely a sampling technique that was not randomly selected. The non-probability sampling technique used in this study is the purposive sampling, which is the technique of selecting subject groups based on certain criteria applied based on the objectives of the research being carried out. In this study, the validity test used was construct validity using the Confirmatory Factor Analysis (CFA) method, namely by paying attention to the factor-loading on each statement item. A statement is said to be valid, if the factor loading is 0.6 [17]. In this study, the reliability test used is Inter-Item Consistency Reliability by looking at the Cronbach's Alpha Coefficient. Hence, an instrument is said to be reliable, if the Cronbach's Alpha is 0.6 [16].

In this study, we used the Structural Equation Modeling (SEM) to analyze the relationship among the variables, in form of path analysis. In this study, SEM analysis was performed using the AMOS software version 21.

\subsection{Statistical-Test Results}

\subsubsection{The Description of Research Subjects}

Table 1 The characteristics of respondents based on gender

\begin{tabular}{clcc}
\hline No & Gender & Frequency $(\mathbf{F})$ & Percentage (\%) \\
\hline 1 & Male & 137 & 68.5 \\
2 & Female & 63 & 31.5 \\
& Total & 200 & 100 \\
\hline
\end{tabular}

Source: Data Processing Results (2020)

Table 2 The characteristics of respondents by age

\begin{tabular}{|c|c|c|c|}
\hline No & Age & Frequency $(F)$ & Percentage $(\%)$ \\
\hline 1 & $<25$ years old & 75 & 37.5 \\
\hline 2 & $\begin{array}{l}25-34 \text { years } \\
\text { old }\end{array}$ & 96 & 48 \\
\hline 3 & $\begin{array}{l}35-44 \text { years } \\
\text { old }\end{array}$ & 22 & 11 \\
\hline 4 & $\begin{array}{l}45-50 \text { years } \\
\text { old }\end{array}$ & 3 & 1,5 \\
\hline 5. & $\begin{array}{l}>50 \text { years old } \\
\text { Total }\end{array}$ & $\begin{array}{c}4 \\
200\end{array}$ & $\begin{array}{c}2 \\
100\end{array}$ \\
\hline
\end{tabular}

Source: Data Processing Results (2020)

Table 3 The characteristics of respondents based on education

\begin{tabular}{clcc}
\hline No & Education & Frequency $(\mathbf{F})$ & Percentage (\%) \\
\hline 1 & Senior High & 12 & 6 \\
& School & & \\
2 & Diploma & 14 & 7 \\
3 & Bachelor & 174 & 87 \\
& (S1/S2/S3) & & \\
& Total & 200 & 100 \\
\hline
\end{tabular}

Source: Data Processing Results (2020)

Table 4 The characteristics of respondents by working period

\begin{tabular}{clcc}
\hline No & $\begin{array}{c}\text { Working } \\
\text { Period }\end{array}$ & Frequency $(\mathbf{F})$ & Percentage (\%) \\
\hline 1 & $>1$ year & 52 & 26 \\
2 & $2-3$ years & 79 & 39.5 \\
3 & $4-5$ years & 43 & 21.5 \\
4 & $>5$ years & 26 & 13 \\
& Total & 200 & 100 \\
\hline
\end{tabular}

Source: Data Processing Results (2020)

\subsection{Validity and Reliability Test}

Table 5 Validity Test

\begin{tabular}{cccccc}
\hline Variable & Indicator & $\begin{array}{c}\text { Professional } \\
\text { Identity }\left(\mathbf{X}_{1}\right)\end{array}$ & $\begin{array}{c}\text { Organizational } \\
\text { Support }\left(\mathbf{X}_{2}\right)\end{array}$ & $\begin{array}{c}\text { Job Satisfaction } \\
(\mathbf{Y})\end{array}$ & $\begin{array}{c}\text { Intention to Quit } \\
(\mathbf{Z})\end{array}$ \\
\hline Professional Identity & $\mathrm{PI}_{1}$ & 0.945 & & & \\
$\left(\mathbf{X}_{1}\right)$ & $\mathrm{PI}_{2}$ & 0.952 & & & \\
& $\mathrm{PI}_{3}$ & 0.916 & & &
\end{tabular}




\begin{tabular}{|c|c|c|c|c|}
\hline \multirow{9}{*}{$\begin{array}{c}\text { Organizational } \\
\text { Support }\left(\mathbf{X}_{2}\right)\end{array}$} & $\mathrm{OS}_{1}$ & 0.929 & & \\
\hline & $\mathrm{OS}_{2}$ & 0.936 & & \\
\hline & $\mathrm{OS}_{3}$ & 0.920 & & \\
\hline & $\mathrm{OS}_{4}$ & 0.890 & & \\
\hline & $\mathrm{OS}_{5}$ & 0.683 & & \\
\hline & $\mathrm{OS}_{6}$ & 0.908 & & \\
\hline & $\mathrm{OS}_{7}$ & 0.919 & & \\
\hline & $\mathrm{OS}_{8}$ & 0.923 & & \\
\hline & $\mathrm{OS}_{9}$ & 0.912 & & \\
\hline \multirow{4}{*}{ Job Satisfaction (Y) } & $\mathrm{JS}_{1}$ & & 0.732 & \\
\hline & $\mathrm{JS}_{2}$ & & 0.733 & \\
\hline & $\mathrm{JS}_{3}$ & & 0.859 & \\
\hline & $\mathrm{JS}_{4}$ & & 0.792 & \\
\hline \multirow{4}{*}{ Intention to Quit (Z) } & $\mathrm{IQ}_{1}$ & & & 0.805 \\
\hline & $\mathrm{IQ}_{2}$ & & & 0.772 \\
\hline & $\mathrm{IQ}_{3}$ & & & 0.790 \\
\hline & $\mathrm{IQ}_{4}$ & & & 0.770 \\
\hline
\end{tabular}

Source: Data Processing Results (2020)

Table 6 Reliability Test

\begin{tabular}{cccc}
\hline Variable & Items & Cronbach's Alpha & Decision \\
\hline Professional Identity & 3 & 0.956 & Reliable \\
Organizational Support & 9 & 0.972 & Reliable \\
Job Satisfaction & 4 & 0.893 & Reliable \\
Intention to Quit & 4 & 0.889 & Reliable \\
\hline \multicolumn{2}{c}{ Source: Data Processing Results $(2020)$} &
\end{tabular}

Source: Data Processing Results (2020)

\subsection{Goodness-of-Fit Test}

Table 7 Model Fit-Test Results (Goodness-of-Fit Model)

\begin{tabular}{ccccc}
\hline $\begin{array}{c}\text { Measurement } \\
\text { Type }\end{array}$ & $\begin{array}{c}\text { Measurement } \\
\text { Goodness-of-Fit }\end{array}$ & Expected Value & Value & Conclusion \\
\hline Absolute Fit & Chi-square $\left(\chi^{2}\right)$ & $<195.973$ & 316.965 & Unacceptable Fit \\
Measures & $\rho$-value & $\geq 0.5$ & 0.000 & Unacceptable Fit \\
& GFI & $\geq 0.9-1$ & 0.906 & Good Fit \\
RMSEA & $\leq 0.08$ & 0.073 & Good Fit \\
Incremental Fit & AGFI & $\geq 0.9-1$ & 0.928 & Good Fit \\
Measures & NFI & $\geq 0.9-1$ & 0.892 & Unacceptable Fit \\
& TLI & $\geq 0.9-1$ & 0.839 & Unacceptable Fit \\
Parsimonius Fit & CFI & $\geq 0.9-1$ & 0.918 & Good Fit \\
Measure & CMIN/DF & Lower Level: 1 & 1.921 & Good Fit \\
\hline
\end{tabular}

Source: Data Processing Results (2020)

\subsection{Hypothesis Tests}

Table 8 The Results of Hypothesis Tests

\begin{tabular}{clccc}
\hline Hypothesis & \multicolumn{1}{c}{ Effect } & Estimate & $\boldsymbol{\rho}$-value & Decision \\
\hline $\mathrm{H}_{1}$ & $\begin{array}{l}\text { Professional Identity }\left(\mathrm{X}_{1}\right) \rightarrow \text { Job } \\
\text { Satisfaction (Y) }\end{array}$ & 0.302 & 0.000 & Accepted \\
$\mathrm{H}_{2}$ & $\begin{array}{l}\text { Organizational Support }\left(\mathrm{X}_{2}\right) \rightarrow \mathrm{Job} \\
\text { Satisfaction }(\mathrm{Y})\end{array}$ & 0.412 & 0.000 & Accepted \\
$\mathrm{H}_{3}$ & $\begin{array}{l}\text { Job Satisfaction }(\mathrm{Y}) \rightarrow \text { Intention to } \\
\text { Quit }(\mathrm{Z})\end{array}$ & -0.401 & 0.000 & Accepted \\
$\mathrm{H}_{4}$ & $\begin{array}{l}\text { Professional Identity }\left(\mathrm{X}_{1}\right) \rightarrow \\
\text { Intention to Quit }(\mathrm{Z})\end{array}$ & -0.148 & 0.012 & Accepted \\
\hline
\end{tabular}




\begin{tabular}{cllll}
\hline $\mathrm{H}_{5}$ & $\begin{array}{l}\text { Organizational Support }\left(\mathrm{X}_{2}\right) \rightarrow \\
\text { Intention to Quit }(\mathrm{Z})\end{array}$ & -0.155 & 0.017 & Accepted \\
$\mathrm{H}_{6}$ & $\begin{array}{l}\text { Professional Identity }\left(\mathrm{X}_{1}\right) \rightarrow \mathrm{Job} \\
\text { Satisfaction }(\mathrm{Y}) \rightarrow \text { Intention to }\end{array}$ & -0.757 & 0.000 & Accepted \\
& $\begin{array}{l}\text { Quit }(\mathrm{Z}) \\
\text { Organizational Support }\left(\mathrm{X}_{2}\right) \rightarrow \mathrm{Job}\end{array}$ & -0.736 & 0.000 & Accepted \\
$\mathrm{H}_{7}$ & $\begin{array}{l}\text { Satisfaction }(\mathrm{Y}) \rightarrow \text { Intention to } \\
\text { Quit }(\mathrm{Z}) \quad \text { Source: Data Processing Results (2020) }\end{array}$
\end{tabular}

\section{DISCUSSIONS}

In this study, it can be seen that the number of respondents based on the gender of XYZ insurance agents in NMV Unit involved in this study was 137 males $(68.5 \%)$ and 63 females $(31.5 \%)$. This shows that the insurance agent XYZ Unit NMV is dominated by male workers who tend to be more persistent and resilient in their work.

In this study it can be seen that the number of respondents based on the age of insurance agents of XYZ in NMV Unit involved in this study was 96 respondents (48\%) aged 25 34 years old. This shows that the insurance agents of XYZ in NMV Unit was dominated by the workers of productive age, between 25 - 34 years old, who are considered to have work experience and high work spirit and discipline resulting in good performance.

In this study, it can be seen that the number of respondents based on the latest education of insurance agent of XYZ in NMV Unit involved in this study, were as many as 174 respondents (87\%) having a university degree (S1 / S2 / S3). This shows that having high education allows the workers to have self-control in carrying out their work and daily responsibilities, and have the ability to well adapt to the environment.

In this study, it can be seen that the number of respondents based on the work period of the insurance agent of XYZ in NMV Unit involved in this study, were 79 respondents (39.5\%) having worked for 2 - 3 years. This shows that the workers have a relatively good retention-rate to the organization.

Based on the validity test, it is known that each statement item from each variable in this study has a factor-loading of 0.6. This indicates that all statement items are declared feasible or valid to be used in this study. Based on the reliability test, the value of Cronbach's Alpha for each variable is greater than 0.6 . This shows that all variables used in this study are feasible or reliable to be used for data analysis purpose.

The results of the Goodness-of-Fit Model test, which are measured using three types of measurements consisting of nine indices, show that the model is declared good fit according to the Absolute Fit Measures, Incremental Fit Measures, and Parsimonius Fit Measures. Overall, it can be concluded that the model contained in this study can predict the relationship between variables well and can be used as a tool in confirming the theory that has been built based on the existing observational data.

Based on the result of data analysis regarding the first hypothesis using AMOS version 21 as displayed in Table 4.15 , the estimate value is 0.302 and $\rho$-value is 0.000
(<0.05). Thus, hypothesis 1 was supported by data, namely professional identity has a positive effect on job satisfaction. The result of this study is in accordance with the previous study conducted by [5] which stated that the positive energy and enthusiasm shown by workers in daily work activities can only be owned by those who have a positive professional identity, and this is proven to be influential in eliminating dissatisfaction that arises in their daily work.

Based on the result of data analysis regarding the second hypothesis, the estimate value is 0.412 and $\rho$-value is 0.000 $(<0.05)$. Thus, hypothesis 2 was supported by data, namely organizational support has a positive effect on job satisfaction. The similar result was also found by [18] who stated that the high level of organizational support results in a significantly higher level of job satisfaction, the existence of organizational support provided by superiors and colleagues and various self-development efforts had a strong correlation with job satisfaction.

Based on the result of data analysis regarding the third hypothesis, the estimate value is -0.401 and $\rho$-value is 0.000 $(<0.05)$. Thus, hypothesis 3 was supported by data, namely job satisfaction has a negative effect on the intention to quit. This study is in accordance with the previous research conducted by [6] which suggested that to get an organization that can work effectively and efficiently, it requires workers who have job satisfaction. Job satisfaction can be achieved through the provision of various rewards both extrinsically and intrinsically, and one of the most influential is the provision of salary increases. This is proven to increase job satisfaction and employee commitment so as to eliminate the intention to quit among the workers.

Based on the result of data analysis regarding the fourth hypothesis, the estimate value is -0.148 and $\rho$-value is 0.012 $(<0.05)$. Thus, hypothesis 4 was supported by data, namely professional identity has a negative effect on the intention to quit. This result is supported by [8], which suggested that every organization has different characteristics, policies, and interests, which create recognition and self-esteem. The higher the level of recognition and self-esteem contained in each individual contributes to the emergence of a subjective feeling of self-worth as a professional, which is interpreted as a professional identity. A professional worker has a higher level of self-confidence and is believed to be able to communicate effectively with other colleagues, so that those workers feel well-accepted in their organizational environment which has an impact on decreasing the intention to quit among the workers. 
Based on the result of data analysis regarding the fifth hypothesis, the estimate value is -0.155 and $\rho$-value is 0.017 $(<0.05)$. Thus, hypothesis 5 was supported by data, namely organizational support has a negative effect on the intention to quit. The result of this research is in accordance with the previous research conducted by [19] mentioning that the organizational support received by a worker is proven to have an influence on increasing the affective and normative commitment in a positive way, an increase in work commitment is in line with an increase in the retention-rate of the worker to the organization he / she serves.

Based on the result of data analysis regarding the sixth hypothesis, the estimate value is -0.757 and $\rho$-value is 0.000 $(<0.05)$. The estimate figure shown by the influence of mediation, shows a greater value when being compared to the direct relationship between the two variables $(-0.757>$ -0.148). Thus, hypothesis 6 was supported by data, namely professional identity has a negative effect on the intention to quit which is fully mediated by job satisfaction. The result found in this study is supported by the result of a similar study conducted by [5], which stated that professional identity is more often indirectly related to the intention to quit with the help of mediation by various other factors. One of the most influential mediating factors is job satisfaction, which has proven to be a fully functional mediator of the relationship that is formed between professional identity and the intention to quit.

Based on the result of data analysis regarding the seventh hypothesis estimate value is -0.736 and $\rho$-value is $0.000(<$ $0.05)$. The estimate figure shown by the influence of mediation, shows a greater value when being compared to the direct relationship between the two variables $(-0.736>$ -0.155). Thus, hypothesis 7 was supported by data, namely organizational support has a negative effect on the intention to quit, which is fully mediated by job satisfaction. The finding in this study is in accordance with that of previous research conducted by [7], which proposed that mostly the organizational support and the intention to quit are related indirectly and is mediated by another factor such as job satisfaction. An organization that gives attention and support to its workers is believed to be able to create high trust from these workers in the organization they serve.

\section{CONCLUSIONS}

Based on data analysis that has been conducted, it can be concluded that (1) professional identity has a positive effect on job satisfaction, (2) organizational support has a positive effect on job satisfaction, (3) job satisfaction has a negative effect on the intention to quit, (4) Professional identity has a negative effect on the intention to quit, (5) Organizational support has a negative effect on the intention to quit, (6) Professional identity has a negative effect on the intention to quit which is fully mediated by job satisfaction, (7) Organizational support has a negative effect on the intention to quit which is mediated fully by job satisfaction.

Based on the overall research results and the conclusions obtained, several suggestions can be provided. The suggestions that can be put forward are as follows:
(1) Strive for various forms of development programs that can support the agents to develop themselves so that they can prepare themselves for higher positions, as well as preparing various other forms of support that can increase job satisfaction which has an impact on the low intention to quit among the agents.

(2) Future research can use other factors that can mediate the influence of professional identity and organizational support on the intention to quit, such as work commitment.

\section{REFERENCES}

[1] Aqil, M., Munir, SS., Ahmed, RR., \& Qadeer, S. (2014). Factors influencing insurance agents' intention to leave: Findings from life insurance sector in Pakistan. International Journal of Technology Marketing, 4(4), 205-206.

[2] Djaelani, F., Keban, JT., Husnan, S., \& Hanafi, MM. (2011). Pertumbuhan industri asuransi di Indonesia: Suatu kajian dari sisi penawaran. Kawistara, 1(3), 257.

[3] Messah, OB (2011). Factors influencing agents' retention in insurance industry: A survey of selected insurance companies in Nairobi (Kenya). Journal of Economics and Sustainable Development, 2(3), 95.

[4] Kumar, M., Jauhari, H., Rastogi, A., Sivakumar, S. (2018). Managerial support for development and turnover intention: Roles of organizational support, work engagement, and job satisfaction. Journal of Organizational Change Management, 31(1), 137-139, 141. DOI: https://doi.org/10.1108/JOCM-06-20170232 .

[5] Zhang, W., Meng, H., Yang, S., \& Liu, D. (2018). The influence of professional identity, job satisfaction, and work engagement on turnover intention among township health inspectors in China. International Journal of Environmental Research and Public Health, 15, 2-3, 9. DOI: https://doi.org/10.3390/ijerph 15050988 .

[6] Azeez, RO., Jayeoba, FI., Adeoye, AO. (2016). Job satisfaction, turnover intention, and organizational commitment. BVIMSR's Journal of Management Research, 8(2), 102, 104, 110-111. DOI: https://doi.org/10.1108/SAJBS-05-2016-0046.

[7] Dawley, D., Houghton, JD., Bucklew, NS. (2010). Perceived organizational support and turnover intention: The mediating effects of personal sacrifice and job fit. The journal of Social Psychology, 150(3), 
238-239, 241, 242, 252. DOI:

https://doi.org/10.1080/00224540903365463.

[8] Hassan, RM., Elhosany, WA. (2017). Professional identity and turnover intention among staff nurses in different sectoral hospital. IOSR Journal of Nursing and Health Science, 6(4), 29-30, 35. DOI: https://doi.org/10.9790/1959-0604012937.

[9] Paidi, Sucherly, Kaltum, U., \& Helmi, A. (2018). Image of Indonesian life insurance companies by their client's trust. Academy of Strategic Management Journal, 17(2), 1.

[10] Mandira, IMC., Putri IGAMAD. (2014). Analisis komparatif kinerja keuangan XYZ dengan PT. Prudential Life Assurance. E-Journal Akuntansi Universitas Udayana, 8(2), 155. DOI: https://doi.org/10.17358/jabm.3.1.131.

[11] Komba, WLM., Anangisye, WAL., Katabaro, JK. (2013). The development of teacher professional identity at the University of Dar es Salaam: Perceptions and influencing factors. Journal of International Cooperation in Education, 15(3), 189-190. DOI: https://doi.org/10.15027/34871.

[12] Behestifar, M. A. (2012). Investigation perceived organizational support on Employee's positive attitudes toward work. Journal of Interdisciplinary Business Research, 432-442.

[13] Kraimer, M.L., Seibert, SE., Wayne, SJ. \& Liden, RC. (2011). Antecedents and outcomes of organizational support for development: The critical role of career opportunities. Journal of Applied Psychology, 96(3), 486. DOI: https://doi.org/10.1037/a0021452.

[14] Zhang, Y., Feng, X. (2011). The relationship between job satisfaction, burnout, and turnover intention among physicians from urban state-owned medical institution in Hubei, China: A cross-sectional study. BMC Health Services Research, 11, 9. DOI: https://doi.org/10.1186/1472-6963-11-235.

[15] Bailey, AA. Albassami, F., Al-Meshal, S. (2016). The roles of employee job satisfaction and organizational commitment in the internal marketingemployee bank identification relationship. International Journal of Bank Marketing, 34(6), 824. DOI: https://doi.org/10.1108/IJBM-06-2015-0097.

[16] Sekaran, U., Bougie, R. (2016). Research method for business: A skill building approach. Ed. ke-7. New York: John Wiley \& Sons, 224, 252, 290.
[17] Malkhantie, A. (2015). Structural equation modeling with AMOS, 22-29, 32.

[18] Ahmad, ZA., Yekta, ZA. (2010). Relationship between perceived organizational support, leadership behavior, and job satisfaction: An empirical study in Iran. Intangible Capital, 6(2), 167, 169, 176. DOI: https://doi.org/10.3926/ic.2010.v6n2.p162-184.

[19] Islam, T., Khan, SR., Kamar, UN., Ahmad, U., Ali, G., Ahmed, I., Bowra, ZA. (2013). Turnover intentions: The influence of perceived organizational support and organizational commitment. Procedia - Socialand Behavioral Science, 103, 1238, 1241. DOI: https://doi.org/10.1016/j.sbspro.2013.10.452.

[20] Alvi, AK., Abbasi, AS., Haider, R. (2014). Relationship of perceived organizational support and employee engagement. Science International, 26(2), $952,954$.

[21] Asmara, AP. (2017). Pengaruh turnover intention terhadap kinerja karyawan rumah sakit bedah Surabaya. JAKI, 5(2), 123-124. DOI: https://doi.org/10.20473/jaki.v5i2.

[22] Baker, WK. (2004). Antecedents and consequences of job satisfaction: Testing a comprehensive model using integrated methodology. Journal of Applied Business Research, 20(3), 32. DOI: https://doi.org/10.19030/jabr.v20i3.2212.

[23] Bektas, C. (2017). Explanation of intrinsic and extrinsic job satisfaction via mirror model. BMIJ, 5(3), 630-631. DOI: https://doi.org/10.15295/bmij.v5i3.118.

[24] Bothma, FC. Roodt, G. (2012). Work-based identity and work engagement as potential antecedents of task performance and turnover intention: Unravelling a complex relationship. SA Journal of Industrial Psychology, 38(1), 13. DOI:

https://doi.org/10.4102/sajip.v38i1.893.

[25] Branch, S. (2002). Who will I be when I leave university: The development of professional identity. Teaching and Educational Development Institute, 1, 9.

[26] Byrne, BM. (2010). Structural equation modeling with AMOS: Basic concepts, applications, and programming. Ed. ke-2. New York: Taylor \& Francis Group, 78-80. DOI: https://doi.org/10.4324/9780203805534.

[27] Cohen, A., Golan, R. (2007). Predicting absenteeism and turnover intentions by past absenteeism and work attitudes. Career Development 
International, 12(5), 417. DOI:

https://doi.org/10.1108/13620430710773745.

[28] Cowin, LS., Maree J., Rhonda GC., \& Herbert WM. (2008). Causal modeling of self-concept, job satisfaction, and retention of nurses. International Journal of Nursing Studies, 45(10), 1450. DOI: https://doi.org/10.1016/j.ijnurstu.2007.10.009.

[29] Dai, K., Qin, X. (2016). Perceived organizational support and employee engagement: Based on the research of organizational identification and organizational justice. Open Journal of Social Sciences, 4, 47. DOI: https://doi.org/10.4236/jss.2016.412005.

[30] Elayati, M. (2015). Pengaruh keadilan imbalan dan gaya kepemimpinan berorientasi tugas terhadap perceived organizational support pada sales PT. Columbindo Perdana cabang Semarang. Skripsi Jurusan Psikologi: Universitas Negeri Semarang.

[31] Hasan, A., Noreen, S., Mohsin, M. (2018). The relationship among perceived organizational support, trust, job satisfaction, and turnover intention: A study of banking sector in Pakistan". International Journal of Human Resource Studies, 8(4), 230-231, 236. DOI: https://doi.org/10.5296/ijhrs.v8i4.13686.

[32] Hong, J.Y. (2010). Pre-service and beginning teacher's professional identity and its relation to dropping out of profession. Teaching and Teacher Education, 26, 1539-1540. DOI: https://doi.org/10.1016/j.tate.2010.06.00.

[33] Iqbal, A. (2010). Employee turnover: Causes, consequences, and retention strategies in the Saudi organizations. The Business Review, 16(2), 278. DOI: https://doi.org/10.5267/j.msl.2018.12.007.

[34] Imran, M., Ali, G., Islam, T. (2014). The relationship between perceived organizational support and turnover intention: Mediating role of affective commitment and job satisfaction". Researched Journal of Applied Sciences, Engineering, and Technology, 8(24), 2424. DOI: https://doi.org/10.19026/rjaset.8.1249.

[35] Jiang, H., Wang, Y., Chui, E., Xu, Y. (2017). Professional identity and turnover intentions of social workers in Beijing, China: The roles of job satisfaction and agency type". International Social Work, 6, 12-13. DOI: https://doi.org/10.1177/0020872817712564.

[36] Johnson, M., Cowin, LS., Wilson, I., \& Young, H. (2012). Professional identity and nursing:

Contemporary theoretical developments and future research challenges. International Nursing Review, 2.
DOI: https://doi.org/10.1111/j.1466-7657.2012.

01013.x.

[37] Kabeel, ARA., Eisa, SAEM. (2017). Relationship between job satisfaction and professional identity among psychiatric nurses. Egyptian Nursing Journal, 14, 10, 14. DOI: https://doi.org/10.4103/20906021.206939 .

[38] Kuo, YK., Su, YY., Chang, BL. (2015). The study on relationships of perceived organizational support and job satisfaction in Taiwan hospitality service industry. Technology Innovation and Industrial Management, 1979-1980.

[39] Malna, MA., Rodhiyah, Dewi, RS. (2014). Pengaruh kompensasi dan motivasi kerja terhadap turnover intention melalui stress kerja karyawan PT. Bank Tabungan Negara kantor cabang Semarang. Diponegoro Journal of Social and Political of Science, 6.

[40] Mandira, IMC., Putri IGAMAD. (2014). Analisis komparatif kinerja keuangan XYZ dengan PT. Prudential Life Assurance. E-Journal Akuntansi Universitas Udayana, 8(2), 155

[41] Murrar, A., Hamad, A. (2013). Relationship between job satisfaction and turnover intention: An empirical study on the IT firms in Palestine. Interdisciplinary Journal of Research in Business, 2(8), 69.

[42] Rahman, W., Nas, Z. (2013). Employee development and turnover intention: Theory validation. European Journal of Training and Development, 37(6), 568. DOI: https://doi.org/10.1108/EJTD-May-20120015 .

[43] Randhawa, G. (2007). Relationship between job satisfaction and turnover intentions: An empirical analysis. Indian Management Studies Journal, 11, 151.

[44] Rhoades, L., Eisenberger, R. (2002). Perceived organizational support: A review of the literature. Journal of Applied Psychology, 87(4), 699-702. DOI: https://doi.org/10.1037/0021-9010.87.4.698.

[45] Robbins, SP., Judge, TA. (2011). Organizational behavior. Ed. ke-15. New Jersey: Pearson, 84-86.

[46] Sabanciogullari, S., Dogan, S. (2015). Relationship between job satisfaction, professional identity, and intention to leave the profession among nurses in Turkey. Journal of Nursing Management, 23, 1077 1078, 1080, 1082. DOI: https://doi.org/10.1111/jonm.12256. 
[47] Shaju, M., Subhashini, D. (2017). A study on te impact of job satisfaction on job performance of employees workin in automobile industry, Punjab, India. Journal of Management Research, 9(1), 118. DOI: https://doi.org/10.5296/jmr.v9i1.10420.

[48] Sugiyono. (2018). Metode penelitian evaluasi (Pendekatan kuantitatif, kualitatif, dan kombinasi). Bandung: Alfabeta, 60-61, 65, 75, 142, 187.

[49] Tsakissiris, J. (2015). Self-interest in career choices in the emerging ICT workforce. Tesis Master of Business: Queensland University of Technology.

[50] Waluyo, M. (2016). Mudah cepat tepat penggunaan tools AMOS dalam aplikasi (SEM). Ed. ke-1. Jawa Timur: UPN "Veteran”, 14-19, 86. 